Tersedia Online di http://journal.unismuh.ac.id/index.php/otoritas

Otoritas : Jurnal Ilmu Pemerintahan, 6 (1), April 2016, 21-27

\title{
Model Pemberdayaan Masyarakat Tunagrahita di Kampung Idiot Kabupaten Ponorogo
}

\author{
Dian Suluh Kusuma Dewi*) \\ Program Studi Ilmu Pemerintahan, Universitas Muhammadiyah Ponorogo, Jalan Budi Utomo No.10, \\ Ponorogo, Jawa Timur, Indonesia, 63451
}

Diterima : 9 Januari 2016; Disetujui : 26 Maret 2016; Dipublikasikan 14 April 2016

\begin{abstract}
Tunagrahita an integral part of the social process in Indonesia. Tunagrahita problems are social problems, because it is a situation that leads to the violation of values, norms, and lead to people being emotional. As a manifestation of the community's efforts to increase social welfare for Tunagrahita, then the various activities of the empowerment-based community resources is necessary, one of them in Kampung Idiot, Ponorogo Regency. The purpose of this study is to look at the model of Tunagrahita community empowerment in the place. The method used is descriptive method with qualitative approach. Data was collected through interviews and documentation. The result Showed model of Tunagrahita Community Empowerment in Kampung Idiot is community empowerment based on a economy strengthening.
\end{abstract}

Keywords: tunagrahita; kampung idiot; community empowerment

\begin{abstract}
Abstrak
Tunagrahita merupakan bagian tak terpisahkan dari proses sosial kemasyarakatan di Indonesia. Permasalahan Tunagrahita merupakan permasalahan sosial, karena merupakan keadaan yang mengarah kepda pelanggaran nilai-nilai, norma, serta mengakibatkan penderita menjadi emosional. Sebagai wujud dari upaya masyarakat terhadap peningkatan kesejahteraan sosial bagi Tunagrahita, maka berbagai kegiatan pemberdayaan yang berbasis sumber daya masyarakat memang perlu dilakukan, salah satunya di Kampung Idiot, Kabupaten Ponorogo. Tujuan penelitian ini adalah untuk melihat model pemberdayaan masyarakat Tunagrahita di tempat tersebut. Metode yang digunakan adalah metode deskriptif dengan pendekatan kualitatif. Teknik pengumpulan data dilakukan dengan wawancara dan dokumentasi. Hasil Penelitian menunjukkan Model Pemberdayaan Masyarakat Tunagrahita di Kampung Idiot adalah pemberdayaan masyarakat berbasis penguatan.
\end{abstract}

Kata kunci : tunagrahita; kampung idiot; pemberdayaan masyarakat

Cara Penulisan Sitasi : Dewi, D.S.A. (2016). Model Pemberdayaan Masyarakat Tunagrahita di Kampung Idiot Kabupaten Ponorogo. Otoritas : Jurnal Ilmu Pemerintahan, 6 (1), 21 $-27$

${ }^{*}$ Penulis Korespondensi.

E-Mail : suluh.dian@gmail.com

Copyright (C) 2016, Otoritas : Jurnal Ilmu Pemerintahan, p-ISSN: 2088-3706, e-ISSN: 2502-9320 
Tersedia Online di http://journal.unismuh.ac.id/index.php/otoritas

Otoritas : Jurnal Ilmu Pemerintahan, 6 (1), April 2016, 22

\section{Pendahuluan}

Tunagrahita merupakan bagian integral bangsa Indonesia, yang tidak terpisahkan dari anggota masyarakat lainnya. Tunagrahita ialah istilah yang digunakan untuk menyebut anak yang mempunyai kemampuan intektual di bawah rata-rata (Somantri, 2006). Mereka mempunyai kedudukan, hak, kewajiban dan peran yang sama sebagai Warga Negara Indonesia. Mereka juga memiliki potensi yang dapat dikembangkan sesuai talenta yang dibawa sejak lahir. Permasalahan Tunagrahita merupakan permasalahan sosial, karena merupakan keadaan yng mengarah kepda pelanggaran nilai-nilai, norma, serta mengakibatkan penderita emosional. Bahkan ekonomi dalam masyarakat tunagrahita tidak dapat berjuang secara maksimal untuk membela diri sendiri. Karena mereka memiliki beberapa keterbatasan, utamanya kemampuan intelektual. Didalam kehidupan sehari-hari secara umum mengalami perlakuan diskriminasi dalam berbagai aspek kehidupan. Adanya anggapan dan pandangan negatif dalam masyarakat, akibat keberadaannya hampir terabaikan. Tunagrahita juga merupakan salah satu masalah dalam penyelenggaraan kesejahteraan sosial, yang memerlukan penangganan secara melembaga, sistematis, dan berkelanjutan.

Seperti yang kita ketahui upaya memberdayakan penyandang tunagrahita, di Negara kita telah memiliki UU dan kebijakan pemerintah. Seperti pada UU No.4 tahun 1997 tentang penyandang cacat, dan juga rancangan aksi nasional penyandang cacat 2009-2014. Namun didalam pelaksanaannya masih jauh dari yang diharapkan baik didalam pengangguran, program, maupun sarana dan prasarana yang tersedia untuk mereka.

Sebagai wujud dari upaya masyarakat terhadap peningkatan kesejahteraan sosial penyandang cacat, berbagai kegiatan pemberdayaan yang ber- sumberdaya masyarakat terhadap penyandang cacat telah dilakukan di berbagai wilayah di Indonesia. Salah satunya diantaranya yaitu kegiatan pemberdayaan tunagrahita di Desa Karangpatihan, Kecamatan Balong, Kabupaten Ponorogo.

Desa Karangpatihan merupakan desa yang terletak cukup jauh dari pusat kota, mayoritas masyarakat mengetahui desa tersebut adalah desa terpencil yang gersang dimana disana hidup banyak masyarakat yang tinggal dengan ketidak layakan seperti mereka hanya tinggal di gubuk kecil yang dindingnya terbuat dari bambu, dan banyak masyarakat disana yang hidup dibawah garis kemiskinan. Di daerah tersebut banyak yang mengalami kekurangan gizi, akses pendidikan dan kesehatan. Para balita yang semestinya rutin melakukan pemeriksaan, malah tidak pernah diperiksakan di puskesmas maupun tempat kesehatan lainnya. Karena masalah-masalah diatas banyak dari warga Desa Karangpatihan yang mengidap down syndrome, hal mendasar penyebab down syndrome (keterbelakangan mental) dapat terjadi karena pemenuhan kebutuhan akan gizi yang tidak cukup, masalah pada kelahiran yang disertai hypoxia (kerusakan otak), dan faktor lingkungan seperti yang dijelaskan diatas. Seiring dengan kejadian masyarakat yang terjangkit down syndrome di desa tersebut yang semakin meluas mengakibatkan desa tersebut sering disebut Kampung Idiot. Selain itu kondisi tersebut diperparah lagi dengan struktur tanahnya tandus karena berada di kawasan pegunungan kapur dan dipengaruhi dengan kurangnya air. Hal tersebut menyebabkan masyarakatnya hidup dalam kondisi yang semakin membuat mereka hidup dalam keprihatinan.

Sedangkan pemerintah pun juga tidak cepat tanggap akan keadaan yang dialami oleh Desa Karangpatihan. Pemerintah pusat seakan menutup mata akan adanya masyarakat yang terjangkit down syndrome. Seandainya memang 
Tersedia Online di http://journal.unismuh.ac.id/index.php/otoritas

Otoritas : Jurnal Ilmu Pemerintahan, 6 (1), April 2016, 23

pemerintah pusat sudah turun tanggan ke desa tersebut tapi sama sekali belum bisa kita lihat hasil yang nyata akan perubahan bahkan perkembangan akan masyarakat tunagrahita tersebut.

Sebelumnya para penyandang tunagrahita di desa tersebut seperti kaum yang terpinggirkan. Mereka yang selama ini hanya dipandang sebelah mata karena kondisinya serta ketidak produktifannya seakan menjadi beban yang memperberat kemiskinan yang melanda Desa Karangpatihan. Data yang dihimpun di Desa Karangpatihan terdapat 290 kepala keluarga (KK) yg hidup dibawah garis kemiskinan, 561 kepala keluarga (KK) yang hampir miskin serta 48 kepala keluarga (KK) yang mempunyai anggota keluarga penyandang tunagrahita. Jumlah penyandang tunagrahita mencapai 98 jiwa dan mayoritas warga berkebutuhan khusus ini masih berusia produktif pada kisaran usia 40 tahun, hanya beberapa diantaranya berusia anak-anak (Pemerintah Desa Karangpatihan Kecamatan Balong Kabupaten Ponorogo, 2014).

Walaupun peran pemerintah belum maksimal dalam pemberdayaan masyarakat tunagrahita, upaya-upaya yang dilakukan oleh pemerintah Desa Karangpatihan dalam rangka pemberdayaan masyarakat tunagrahita diatas, telah dilakukan dalam berbagai model pemberdayaan, sebagaimana tujuan utama pemberdayaan adalah memperkuat kekuasaan masyarakat, khususnya kelompok lemah yang memiliki ketidakberdayaan, baik karena kondisi internal, maupun karena kondisi eksternal. (Suharto, 2005).

Model pemberdayaan yang ada salah satunya dengan adanya pendirian BLK (Balai Latihan Kerja) yang dimana mayoritas yang di BLK merupakan para tunagrahita dan perkembangan terkini di wilayah tersebut, masyarakat tunagrahita sudah mengalami perkembangan yang cukup baik, selain itu mereka yang dulunya sering dianggap menyusahkan war- ga lainnya sekarang sudah berdaya mengembangkan diri melalui programprogram yang dibuat oleh Pemerintah Desa Karangpatihan Kecamatan Balong Kabupaten Ponorogo.

Berbagai kajian tentang pemberdayaan masyarakat utamanya terhadap masyarakat difabel atau disabilitas dipaparkan dalam beberapa penelitian terdahulu. Seperti penelitian Santoso dan Jacky (2013) tentang solidaritas virtual dan pemberdayaan difabel dalam Blogosphere Indonesia yang menjabarkan pentingnya keberadaan jargon untuk membangun solidaritas virtual dalam pemberdayaan difabel, yaitu persaudaraan, diskriminasi, dan we are subject.

Surwanti (2014) meneliti tentang model pemberdayaan ekonomi penyandang disabilitas di Indonesia, Penelitian ini meneliti pihak yang telah melakukan pemberdayaan ekonomi bagi penyandang disabilitas serta konsep pemberdayaan pemberdayaan ekonomi bagi penyandang disabilitas yang telah diimplementasikan. Hasil penelitian menunjukkan penanggung jawab pelaksana pemberdayaan ekonomi penyandang disabilitas memang masih menekankan pada peran Kementerian Sosial, penanganan interdepartemental dan interinstitusi sudah dilakukan, namun peran swasta belum berjalan dengan dengan baik. Implementasi pemberdayaan kepada penyandang disabilitas di Indonesia masih banyak menjumpai persoalan yang memerlukan pembenahan diberbagai sisi.

Dalam penelitian lain, Rahayu dan Dewi (2013), meneliti tentang Pelayanan Publik Bagi Pemenuhan Hak-Hak Disabilitas Di Kota Yogyakarta yang membahas tentang pentingnya keterlibatan pemerintah dalam pemberdayaan dan pemenuhan hak-hak disabilitas dalam pelayanan publik baik dalam bidang pendidikan, kesehatan, pelayanan sosial, ketenagakerjaan, dan fasilitas umum.

Berdasarkan beberapa penelitian 
Tersedia Online di http://journal.unismuh.ac.id/index.php/otoritas

Otoritas : Jurnal Ilmu Pemerintahan, 6 (1), April 2016, 24

terdahulu, maka penelitian ini berupaya untuk mengetahui model pemberdayaan masyarakat tunagrahita yangberada di Kampung Idiot, Kabupaten Ponorogo.

\section{Metode Penelitian}

Dalam penelitian ini sesuai dengan judul penulis memilih obyek penelitian di Kampung Idiot yang berada di Desa Karangpatihan Kecamatan Balong Kabupaten Ponorogo dengan pertimbangan Desa Karangpatihan merupakan desa yang terpencil yang dimana terdapat banyak masyarakatnya yang menderita tunagrahita, selain itu keberadaan Kepala Desa Karangpatihan yang baru dengan visi utama untuk mengembangkan masyarakat Kampung Idiot yang produktif dan berdaya saing, selain itu semangat besar yang dimiliki oleh pejabat desa yang baru memberikan harapan terkait masa depan pemberdayaan di Kampung Idiot.

Dalam penentuan informan, penulis menggunakan purposive sampling yaitu dengan menyaring sebanyak mungkin informasi dari berbagai sumber dan menggali informasi yang akan menjadi dasar teori. Maka dalam penelitian ini, peneliti mengambil 9 informan sebagaimana yang tertera dalam tabel 1.

Adapun dalam metode pengumpulan data, penulis menggunakan metode wawancara dengan teknik interview. Dalam metode wawancara, informan juga terdiri dari Pemerintah Desa Karangpatihan bersama perangkat desa dimana tempat Kampung Idiot berada, tokoh masyarakat, dan masyarakat di Kampung Idiot.

Selain itu dalam agar penelitian ini mendapatkan hasil yang lengkap, penulis juga menggunakan metode dokumentasi dalam mengadakan penelitian ini. Metode dokumentasi juga digunakan untuk melengkapi data yang telah didapat sebelumnya. Sehingga diharapkan dapat memperoleh kebenaran dan ketelitian yang semaksimal mungkin sesuai apa yang diharapkan. Metode ini dilakukan dengan pengamatan dan pencatatan secara sistematis terhadap gejala yang tampak pada subjek penelitian yang bertujuan untuk melengkapi obeservasi dan wawancara yang mendalam.

Sedangkan dalam menggunakan teknik analisis data, penulis menggunakan teknik analisis data kualitatif dengan model interaktif.

Metode penelitian ini digunakan agar dapat mencapai tingkat keakuratan yang tinggi dalam penelitian mengenai model pemberdayaan masyarakat tunagrahita di Kampung Idiot Kabupaten Ponorogo.

\section{Hasil dan Pembahasan}

Berdasarkan hasil wawancara dan dokumentasi yang dilakukan penulis,

Tabel 1. Data Informan (Hasil Penelitian, 2015)

\begin{tabular}{|l|l|l|l|l|l|}
\hline No & Nama & $\begin{array}{l}\text { Jenis } \\
\text { Kelamin }\end{array}$ & Pekerjaan & PENDIDIKAN & ALAMAT \\
\hline $\mathbf{1 .}$ & Eko Mulyadi & L & Kepala Desa & SMKN & Ds. Karangpatihan \\
\hline $\mathbf{2 .}$ & Samuji & L & Jogoboyo II & SLTA & Ds. Karangpatihan \\
\hline $\mathbf{3 .}$ & Paimin & L & Kebayan V & SLTA & Ds. Karangpatihan \\
\hline $\mathbf{4 .}$ & Nyamut Teguh & L & Modin III & SLTA & Ds. Karangpatihan \\
\hline $\mathbf{5 .}$ & Daud & L & Wiraswasta & SLTA & Ds. Karangpatihan \\
\hline $\mathbf{6 .}$ & Tukimah & P & Tani & SD & Ds. Karangpatihan \\
\hline $\mathbf{7 .}$ & Gimun & L & Tani & SMP & Ds. Karangpatihan \\
\hline $\mathbf{8 .}$ & Sipon & P & Tani & SD & Ds. Karangpatihan \\
\hline $\mathbf{9 .}$ & Sutris & L & Pelajar & SMP & Ds. Karangpatihan \\
\hline
\end{tabular}

Copyright (C) 2016, Otoritas : Jurnal Ilmu Pemerintahan, p-ISSN: 2088-3706, e-ISSN: 2502-9320 
Tersedia Online di http://journal.unismuh.ac.id/index.php/otoritas

Otoritas : Jurnal Ilmu Pemerintahan, 6 (1), April 2016, 25

kemudian penulis menganalisa data dan mendapatkan hasil dan pembahasan dari penelitian yang dilakukan sebagaimana yang ada pada sub bab 3.1 dan 3.2.

\subsection{Pemberdayaan masyarakat tunagrahi- ta di Kampung Idiot}

Secara umum masyarakat tunagrahita di Kampung Idiot Desa Karangpatihan Kecamatan Balong Kabupaten Ponorogo diarahkan dalam beberapa upaya pemberdayaan dalam rangka meningkatkan daya produktif, yaitu :

1. Adanya upaya pemberdayaan tunagrahita di BLK Karangpatihan Bangkit. Upaya pemberdayaan masyarakat tunagrahita di Kampung Idiot yang berada di Desa Karangpatihan Kecamatan Balong Kabupaten Ponorogo dilakukan di BLK (Balai Latihan Kerja) dimana disana dilakukan pelatihan membuat keset, tasbih dan juga lampion seperti yang dijelaskan Bapak Eko Mulyadi selaku Kepala Desa Karangpatihan pada wawancara, hari/tanggal sabtu, 28 maret 2015 bahwa upaya pemberdayaan khusus untuk tunagrahita dalam membuat lampion sudah tidak dilakukan kembali karena terkendala bahan yang mahal. Sedangkan Bapak Samuji selaku Jogoboyo Desa Karangpatihan menjelaskan bahwa Upaya pemberdayaan di Desa Karangpatihan yang bertempat di BLK (Bina Latihan Kerja) pertama kali diajarkan membuat tasbih dan keset dengan alat dan bahan yang telah di sediakan oleh pihak desa. Sedangkan menurut Bapak Daud selaku mantan Kepala Desa Karangpatihan untuk pembuatan keset dan tasbih yang bertempat di BLK, mereka dilatih secara perlahan dan memerlukan waktu yang cukup lama saat proses pengarahan dalam pembuatan keset. Semenjak adanya program pemberdayaan di BLK tersebut masyarakat tunagrahita sudah tidak lagi yang mengganggur, bahkan ada sebagian masyarakat yang membuat keset dirumah sendiri, seperti yang sudah dijelaskan oleh Bapak Gimun selaku masyarakat yang mendapatkan bantuan.

2. Diadakannya kegiatan pemberdayaan lele yang merupakan upaya pemberdayaan yang berhasil dilakukan di Kampung Idiot Desa Karangpatihan. Diimana sampai saat ini sudah terdapat 90 kolam ikan lele yang terletak disetiap depan rumah masyarakat tunagrahita, selain itu pemerintah desa juga memberikan bibit lele dan pakan lele guna untuk pembudidayaan yang dilakukan oleh masyarakat tunagrahita seperti yang sudah dijelaskan oleh Bapak Eko Mulyadi Kepala Desa Karangpatihan Dimana di Desa Karangpatihan Kecamatan Balong Kabupaten Ponorogo pada wawancara Sabtu, 28 Maret 2015. Setelah hasil pemanenan yang dilakukan selama 3 bulan, masyarakat tunagrahita akan mendapatkan keuntungan bersih sebesar Rp100.000,sampai Rp 200.000,- seperti yang sudah dijelaskan oleh Bapak Daud selaku mantan Kepala Desa Karangpatihan. Sedangkan menurut Ibu Sipon, selaku ibu salah satu masyarakat masyarakat tunagrahita yang mendapatkan bantuan ternak lele menjelaskan bahwa dalam proses pemberdayaan lele tersebut masih memerlukan arahan dan pengawasan dari pihak desa maupun pihak masyarakat sendiri.

3. Hadirnya kegiatan inovatif berupa pemberdayaan dengan cara ternak kroto untuk sekarang ini masih dalam uji coba yang dilakukan di rumah bapak paimin. Seandainnya proses budidaya kroto tersebut berhasil nantinya akan diterapkan kembali kepada masyarakat tunagrahita di Desa Karangpatihan seperti yang telah dijelaskan oleh Bapak Eko Mulyadi Kepala Desa Karangpatihan pada hari 
sabtu, 28 Maret 2015. Sedangkan menurut Bapak Paimin selaku kebayan $\mathrm{V}$ menjelaskan bahwa pemberdayaan kroto merupakan peluang pemberdayaan yang hasilnya sangat memuaskan karena hasil dari telur kroto dapat dijual dan digunakan untuk pakan burung dengan harga kroto yang tergolong cukup mahal.

4. Diadakannya kegiatan pemberdayaan ternak ayam kampung yang dilakukan di Desa Karangpatihan yang dimana masyarakat tunagrahita diberikan 1 induk ayam jantan dan betina, sedangkan untuk hasil anakan ternak ayam tersebut diharapkan pihak desa dapat dilakukan secara berkelanjutan bisa di peliharan. Dan untuk ayam yang sudah tua bisa dijual nantinya seperti yang dijelaskan oleh Bapak Eko Mulyadi Kepala Desa Karangpatihan. Sedangkan menurut Bapak Nyamut Teguh, selaku Modin III menjelaskan pihak Desa Karangpatihan juga membuat peternakan ayam pedaging dengan mengajak beberapa tunagrahita. Sedangakan menurut Bapak Sutris selaku salah satu pihak masyarakat yang juga ikut membantu pemeliharaan di peternakan ayam kampung. Ditempat peternakan tersebut pihaknya mengajak 4 orang tunagrahita untuk membantu proses budidaya ternak ayam kampung, tetapi untuk saat ini tunagrahita tersebut tidak bekerja kembali di peternakan ayam kampung.

5. Kegiatan pemberdayaan ternak kambing yang dilakukan di Kampung Idiot, Desa Karangpatihan, pemerintah desa memberikan 1 ekor kambing kepada setiap masyarakat tunagrahita, selanjutnya kambing-kambing tersebut dipelihara dan dapat disilangkan, setelah kambing tersebut beranak diharapakan hasil anakan bisa di pelihara secara berkelanjutan dan untuk kambing yang sudah tua bisa dijual nantinya dan dapat mejadi tambahan ekonomi sumber tambahan untuk para tunagrahita, seperti yang telah dijelaskan oleh Bapak Eko Mulyadi selaku Kepala Desa Karangpatihan pada wawancara hari sabtu, 28 Maret 2015. Sedangkan menurut Ibu Sipon, selaku ibu salah satu masyarakat masyarakat tunagrahita yang mendapatkan bantuan 1 ekor kambing menjelaskan bahwa setiap tunagrahita mendapatkan 1 ekor kambing untuk $1 \mathrm{KK}$. Dimana hasil dari ternak kambing tersebut sangat membantu perekonomian masyarakat tunagrahita selain itu mereka dapat hidup mandiri.

\subsection{Hasil pemberdayaan masyarakat tunagrahita untuk menentaskan kem- iskinan di Kampung Idiot}

Hasil dari berbagai upaya permberdayaan yang diterapkan di Desa Karangpatihan seperti pemberdayaan keset, tasbih, ternak lele, ternak ayam, dan ternak kambing yang sudah dijelaskan Bapak Eko Mulyadi selaku Kepala Desa Karangpatihan pada wawancara, hari/ tanggal minggu, 29 maret 2015 berdampak positif meningkatkan pendapatan perekonomian masyarakat tunagrahita di Kampung Idiot.

Hal tersebut dapat dilihat dari hasil ternak mereka yang sekarang bertambah, pendapatan mereka, dari yang dulunya masyarakat tunagrahita tidak memegang uang sedikitpun, setelah mengikuti beberapa upaya pemberdayaan yang telah dilaksanakan pihak desa mereka menjadi masyarakat yang mempunyai pendapatan sendiri dan mampu untuk membiayai kehidupan mereka sehari-hari. Hasil yang utama dari model pemberdayaan ini ialah mereka yang dulunya hanya diam dipinggiran jalan, sekarang menjadi mempunyai kegiatan seperti memberi makan ternak mereka seperti lele, ayam, kambing. Dan ada juga sebagian yang membuat keset di BLK, walau terdapat kendala yang dialami 
Tersedia Online di http://journal.unismuh.ac.id/index.php/otoritas

Otoritas : Jurnal Ilmu Pemerintahan, 6 (1), April 2016, 27

pihak desa terkait pemberdayaan ini.seperti ari segi biaya pemberdayaaan dan mengajari para masyarakat tunagrahita tersebut.

Sedangkan menurut Bapak Samuji, Selaku pihak yang ikut membantu di BLK menyatakan bahwa dari beberapa upaya pemberdayaan tunagrahita yang ada di Kampung Idiot, hasil yang dapat dilihat dari masyarakat tunagrahita adalah saat ini sudah semakin berdaya, mereka bisa bekerja walau dengan keterbatasan, walau hasil yang mereka peroleh tidak banyak tetapi setidaknya mereka tidak dianggap menyusahkan masyarakat lainnya seperti yang dijelaskan Bapak Paimin, selaku kebayan IV.

Selain itu hasil dari program ternak lele bisa dikatakan dapat merentaskan kemiskinan para tunagrahita di Desa Karangpatihan, karena dengan mereka memiliki pendapatan Rp 100.000,- sampai Rp 200.000,- setiap 3 bulan sekali, seperti yang diungkapkan Bapak Nyamut Teguh selaku modin III. Selain itu menurut Bapak Gimun selaku saudara salah satu masyarakat tunagrahita menyatakan bahwa hasil dari pemberdayaan tunagrahita dirasa sudah cukup ada perubahan positif salah satunya mereka menjadi memunyai kegiatan dirumah dan mendapatkan uang dari berternak lele, ayam, dan kambing di rumah.

\section{Kesimpulan}

Dari hasil penelitian diatas, maka dapatlah diambil kesimpulan bahwa Model Pemberdayaan Masyarakat Tunagrahita di Kampung Idiot Kabupaten Ponorogo adalah penguatan ekonomi dengan melakukan beberapa kegiatan pemberdayaan yaitu, pemberdayaan masyarakat di Balai Latihan Kerja dengan melakukan pelatihan pembuatan keset, tasbih, dan lampion. Selanjutnya pemberdayaan ternak ikan lele, lalu pemberdayan ternak kroto yang masih dalam proses uji coba, dan pemberdayaan ternak ayam kampung yang dilakukan di
Kampung Idiot yang dimana masyarakat tunagrahita diberikan sepasang induk ayam, sedangkan untuk hasil anakan ternak ayam tersebut diharapkan oleh pihak pemerintah desa dapat dilakukan secara berkelanjutan dengan proses pemeliharaan.

\section{Ucapan Terima Kasih}

Atas selesainya penelitian dan penulisan karya ilmiah ini, saya menghaturkan terima kasih kepada pihak-pihak yang ikut serta mendukung, memberi saran dan kritik selama penelitian dan penulisan ini berlangsung, terkhusus kepada Civitas Akademika Program Studi Ilmu Pemerintahan, Fakultas Ilmu Pemerintahan, Universitas Muhammadiyah Ponorogo dan pihak Pemerintah Desa Karangpatihan, Kecamatan Balong, Kabupaten Ponorogo, tempat Kampung Idiot dan kegiatan pemberdayaan berada.

\section{Daftar Pustaka}

Pemerintah Desa Karangpatihan Kecamatan Balong Kabupaten Ponorogo. (2014). Profil Desa Karangpatihan Kecamatan Balong Kabupaten Ponorogo Tahun 2014. Ponorogo.

Rahayu, S., \& Dewi, U. (2013). Pelayanan Publik Bagi Pemenuhan Hak-Hak Disabilitas di Kota Yogyakarta. NATAPRAJA, 1(1).

Santoso, A.B., Jacky, M. (2013). Solidaritas Virtual dan Pemberdayaan Difabel dalam Blogosphere Indonesia. Jurnal Paradigma, 1 (3), 1-6.

Somantri, S. (2006). Psikologi Anak Luar Biasa. PT. Refika Aditama. Bandung

Suharto, E. (2005). Membangun masyarakat, memberdayakan rakyat: Kajian strategis pembangunan kesejahteraan sosial dan pekerjaan sosial. Bandung: Refika Aditama.

Surwanti, A. (2014). Model Pemberdayaan Ekonomi Penyandang Disabilitas di Indonesia. Jurnal Manajemen Bisnis, 5 (1), 40-58. 